\title{
Knowledge, Attitudes and Practices on the Disposal of Sharps in Patients of the UP-Philippine General Hospital Diabetes Clinic
}

\author{
Leslie Quiwa and Cecilia Jimeno \\ Section of Endocrinology, Diabetes and Metabolism, Department of Medicine \\ University of the Philippines-Philippine General Hospital Manila
}

\begin{abstract}
Introduction. Diabetics using insulin are the largest group of patients that use syringes and needles outside of the hospital. Despite this, few studies have been done regarding the disposal of sharps of these patients in the community setting.

Objectives. The objective of phase 1 was to create a validated, self-administered questionnaire to assess the knowledge, attitude and practices of diabetic patients with regard to the disposal of sharps in the community setting. The objectives of phase 2 were to assess the knowledge, attitude and practices of these patients and identify which factors influence these characteristics.

Methodology. Literature review and a focus group discussion were conducted. A conceptual framework based on the Health Belief Model was created. Questionnaire items were reviewed by an expert panel, translated into Filipino and pre-tested. The final questionnaire was administered to 130 patients.

Results. Majority of patients (82\%) disposed of their sharps through the community garbage collection and most $(76 \%)$ used a sharps container. Less than one-fourth $(23.7 \%)$ had acceptable disposal techniques. Respondents had moderate knowledge (mean score of $62.2 \%$ ) and positive attitude (mean score of 3.95 out of 5 ) towards sharps disposal. A longer duration of diabetes mellitus (DM) and insulin use negatively influenced disposal practices. Attitude was positively influenced by needle stick injury to self and college education, but being married exerted a negative influence.
\end{abstract}

Conclusion. The majority of patients at the UP-PGH DM clinic have improper sharps disposal practices, and need to be better educated about proper techniques.

Keywords: sharps disposal, diabetes mellitus, insulin syringe, insulin needles

\section{INTRODUCTION}

In the United States, approximately eight million people use syringes at home, generating three billion used needles each year. ${ }^{1}$ Diabetics not only use insulin needles on a regular basis but also use lancets for blood sugar monitoring. Collectively, these objects are called "sharps."

The management of sharps is the responsibility of health care institutions whose health care workers (HCWs) routinely use them. In this setting, there are procedures and policies for the handling and disposal of sharps, but the same is not true in the community. The Philippines currently has no ordinances that regulate the disposal of sharps waste at the community level and poses a threat to public health and safety, and in particular, to garbage disposal workers. Discarded needles may expose waste workers to potential needle stick injuries and infection,

e-ISSN 2308-118X

Printed in the Philippines

Copyright (C) 2014 by the JAFES

Received April 26, 2014. Accepted May 30, 2014

http://dx.doi.org/10.15605/jafes.029.02.07 since used needles can transmit diseases such as HIV and hepatitis $B .^{2}$

The objective of phase 1 was to create a validated, selfadministered questionnaire to assess the knowledge, attitudes and practices of diabetic patients with regard to the disposal of insulin syringes and needles in the community setting. The objectives of phase 2 were 1) to determine the practices of diabetic patients with regard to their disposal of insulin syringes or needles; 2) to assess their knowledge regarding the correct use of insulin syringes and needles, the hazards of improper disposal, and measures that should be taken to ensure their safe disposal; 3) to assess their attitude towards the safe disposal of sharps; and 4) to identify which factors influence knowledge, attitude and practices towards sharps disposal.

Corresponding author: Leslie Q. Quiwa, MD

Section of Endocrinology, Diabetes and Metabolism

University of the Philippines-Philippine General Hospital

Taft Avenue, Ermita

1000 Manila, Philippines

Tel. No.: +632-554-8400 local 3230

E-mail:lesq2@yahoo.com 


\section{METHODOLOGY}

\section{Phase 1}

A PubMed search using a combination of the keywords "diabetes," "sharps," "disposal," "needles," and "syringe" yielded eight relevant studies. Six full text articles were retrieved; two had their abstracts available. No local studies were identified except for an unpublished study done by the authors in $2010 .^{3}$ One study had the actual questionnaire available, while two studies listed the items present in their questionnaire.

The study protocol and informed consent forms were submitted to and approved by the University of the Philippines-Manila Research Ethics Board.

\section{Focus Group Discussion}

A focus group discussion (FGD) was done to verify if the concepts regarding sharps disposal taken from foreign literature were locally applicable and elucidate those that might be unique to the Filipino setting. Five female and three male patients were recruited from the UP-PGH Diabetes Clinic and separate FGD sessions were conducted for female and male participants.

\section{Conceptual Framework}

A conceptual framework was developed to integrate the concepts derived from the review of literature and FGD.
This was based on the Health Belief Model (HBM), one of the most widely used theories on health behavior that focus on the beliefs and actions of individuals. ${ }^{4}$ The HBM as applied to the concepts pertaining to sharps disposal is illustrated in Figure 1.

The conceptual framework was used to guide the development of the questionnaire. Socio-demographic factors and clinical factors related to DM were collected. Knowledge pertaining to proper sharps handling and disposal was assessed with 10-item multiple choice items, which also covered other concepts such as disease transmission. The concepts regarding benefits of proper disposal and barriers to this were tackled in nine questions designed to assess attitude. Sources of disposal advice were identified and in addition, patient's own initiative to seek advice was also documented.

\section{Development of Questionnaire Items}

The questionnaire items adapted from foreign literature were evaluated in terms of best practice for questionnaire design and for factual correctness. Several questions were rewritten, while others were not adapted if not deemed pertinent. New items were created using data from the literature review, results of the focus group discussion and the authors' unpublished study. ${ }^{3}$

The output of these processes was a preliminary questionnaire that was critiqued by a medical

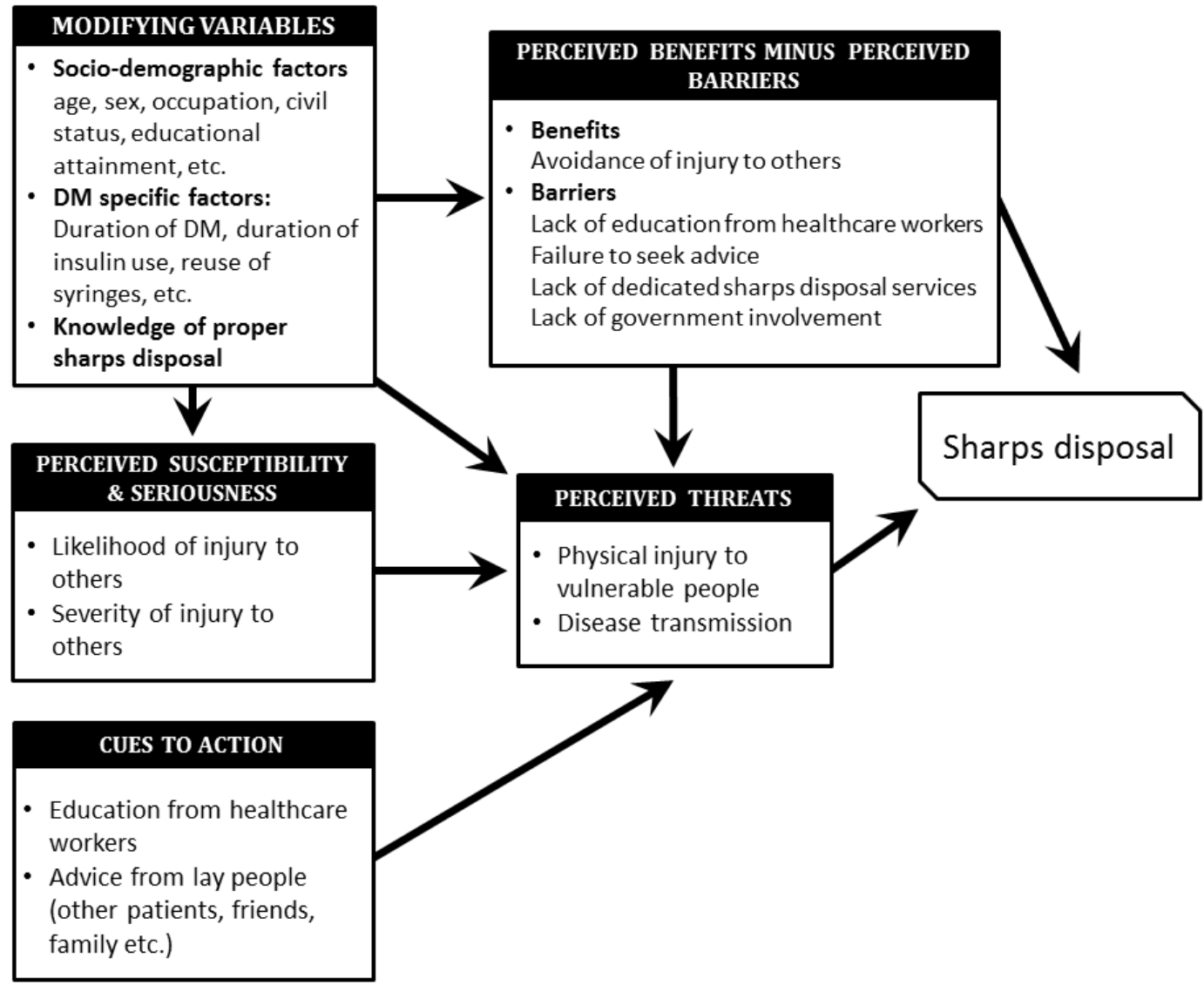

Figure 1. Conceptual framework based on the Health Belief Model 
anthropologist from the clinical epidemiology department. Items that were considered leading were rephrased and suggestions to increase clarity of the items and collect additional data were used to improve the preliminary questionnaire. An endocrinologist reviewed the questionnaire and suggested to revise the knowledge items from a true/false format to multiple choice questions instead. Guides on insulin syringe safety and sharps disposal intended for lay persons were used to support the veracity of the items..$^{5-7}$

The preliminary questionnaire was submitted to the University of the Philippines (U.P.)-Manila Sentro ng Wikang Pilipino for translation into Filipino.

\section{Phase 2}

A total of 130 patients from the UP-PGH Diabetes Clinic participated in the second phase of the study. Inclusion criteria included adult patients (19 years of age or older) who had been using insulin for at least one month. Patients who were illiterate, those with gestational diabetes mellitus and those with difficulty reading the questionnaire due to poor visual acuity were excluded from the study.

\section{Statistical Analysis}

For phase 1, a biostatistician was consulted and a sample size of 124 patients was computed for a confidence level of $95 \%$, relative error of $7.5 \%$ and non-response rate of $10 \%$ with respect to the knowledge of proper sharps disposal, using PASS software.

The data from phase 2 of the study were analyzed by a biostatistician using STATA v12. Multiple logistic regression was done to see which factors were predictive of proper sharps disposal. Linear regression was used to determine which factors influenced the knowledge and attitude scores of the respondents. Item analysis of the multiple-choice questions in the knowledge section was done using PIA v.3, a non-commercial item analysis program used previously to analyze Philippine nationallevel examinations.

\section{RESULTS}

\section{Phase 1}

The preliminary questionnaire was pre-tested on 12 patients from the UP-PGH Diabetes Clinic. The respondents took an average of 13 minutes to answer the questionnaire, with a range of 8 to 20 minutes. Majority found the questionnaire easy to understand. A few items were reworded for clarity.

The revised questionnaire was administered to 81 patients. Cronbach's alpha analysis was done for the knowledge and attitudes section and was 0.44 and 0.62 respectively.

\section{Phase 2}

A total of 130 diabetic patients participated and fully completed the survey (Table 1). Majority of the respondents were female $(65.3 \%)$, married $(59.7 \%)$ and unemployed $(71.5 \%)$. There were nearly equal numbers of high school and college graduates at $32.6 \%$ and $31.8 \%$ respectively. Mean duration of diabetes mellitus was 13.6 \pm 8.5 years, while mean duration of insulin use was approximately half, at $6.7 \pm 6.0$ years. Majority $(62.7 \%)$ had children at their place of residence.

Table 1. Demographic and clinical characteristics of the respondents, $\mathrm{N}=130$

\begin{tabular}{cll}
\hline \multicolumn{1}{c}{ CHARACTERISTICS } & \\
\hline Age & & \\
Sex & Male & \\
& Female & \\
Civil status & $45(34.7 \%)$ \\
Single & $85(65.3 \%)$ \\
Married & \\
Separated & $27(20.9 \%)$ \\
Widowed & $77(59.7 \%)$ \\
Occupation & $14(10.8 \%)$ \\
Employed & $11(8.5 \%)$ \\
Self-employed & $11(8.5 \%)$ \\
Not employed & $11(8.5 \%)$ \\
Retired & $93(71.5 \%)$ \\
Education & $15(11.5 \%)$ \\
Elementary & $28(21.7 \%)$ \\
High school & $42(32.6 \%)$ \\
Vocational & $15(11.6 \%)$ \\
College & $41(31.8 \%)$ \\
Graduate studies & $3(2.3 \%)$ \\
Duration of diabetes mellitus & $13.6 \pm 8.5$ years \\
Duration of insulin use & $6.7 \pm 6.0$ years \\
Presence of children at place of residence & $79(62.7 \%)$ \\
\hline
\end{tabular}

Characteristics pertaining to the use and disposal of insulin syringes are summarized in Table 2. Most of the respondents used insulin stored in vials (62.7\%). Majority of sharps were disposed through community garbage collection $(82 \%)$, either mixed loosely with household waste $(13.0 \%)$ or placed in a container $(76.0 \%)$, although $11 \%$ practiced both, a sharps container was not used regularly. The most common containers used were plastic bags (38.9\%) and plastic bottles (33.6\%). Slightly more than a third of the respondents (38.4\%) reported pulling or cutting insulin needles prior to disposal.

Out of 129 respondents $32.6 \%$ practiced insulin injection outside the home and of these, $66.7 \%$ brought their sharps back, while the remainder disposed of them in the nearest trash can. Majority $(80.0 \%)$ reused their insulin needles or syringes. Only $40.3 \%$ reported not having received sharps disposal advice. Doctors were the most common source $(48.5 \%)$, followed by nurses $(21.6 \%)$ and family members $(13.4 \%)$. Only $23.5 \%$ indicated that they had previously asked a doctor for advice.

\section{Knowledge}

The knowledge of the participants regarding the proper use and disposal of insulin syringes was evaluated using 10 multiple choice questions. Three major concepts were 
covered: proper syringe/needle use; hazards of improper disposal; and proper syringe/needle disposal practices with two, three and five items respectively. The mean score of the participants was $62.2 \pm 15.7 \%$, with fairly similar scores across the three domains (range of $60-66 \%$ ).

Table 2. Characteristics related to the use and disposal of insulin syringes and needles*

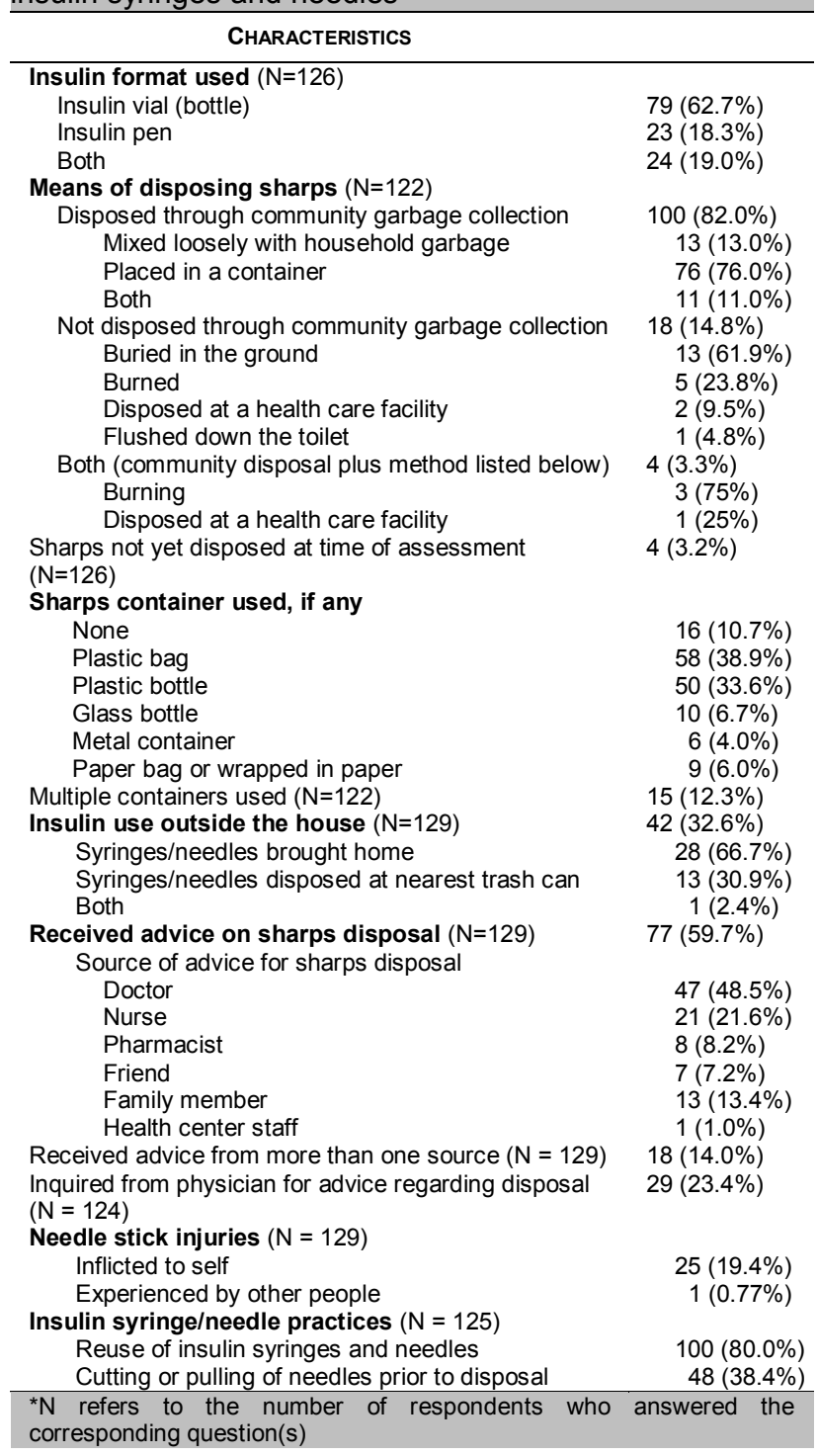

Item analysis was done and the mean item difficulty index (p-value) was 0.623 , corresponding to a test of moderate difficulty. This falls within the recommended mean $\mathrm{p}$ value of $0.6-0.8$ for a four-option MCQ test., 8 Item discrimination was computed using the discrimination index (DI) and point-biserial with acceptable values of $>$ 0.2 for both measures. ${ }^{10-112}$ All the items had acceptable discrimination based on the two measures, with values ranging from $0.22-0.43$ and 0.31 to 0.53 respectively, with the exception of one item with a DI of 0.086 .

\section{Attitude}

The section of the questionnaire evaluating attitude was comprised of nine items covering five concepts (Table 3 ). A 5-point Likert scale on agreement was used, ranging from strongly agree (score of 5) to strongly disagree (score of 1 ). The mean score of the respondents was $3.90 \pm 0.58$, corresponding to a positive attitude.

\section{Factors influencing proper disposal, knowledge and attitude}

Several factors were analyzed to determine which were predictive of proper sharps disposal (Table 4). Proper disposal was defined as the use of a plastic bottle or metal container to hold the sharps prior to disposal, as recommended by guides from the US EPA and FDA. ${ }^{6,7}$ Both a longer duration of diabetes and longer duration of insulin use negatively influenced proper disposal with odds ratios of 0.941 and 0.904 respectively.

Factors that influenced the knowledge level of the respondents were also analyzed. Practice of proper disposal, history of needle stick injury to self, college education, male sex and a higher attitude level were associated with a higher knowledge score but none of these reached statistical significance.

Similarly, analysis was done to determine factors predictive of attitude. History of self-inflicted needle stick injury and college education were associated with a more positive attitude towards proper disposal, while the opposite was observed for being married (Table 5).

Table 3. Distribution of scores per attitude concept

\begin{tabular}{|c|c|c|c|c|c|}
\hline CONCEPT & ITEM & $\begin{array}{l}\text { MEAN SCORE } \\
\text { PER ITEM }\end{array}$ & ATTITUDE* & $\begin{array}{l}\text { MEAN SCORE } \\
\text { PER DOMAIN }\end{array}$ & ATTITUDE* \\
\hline \multirow{4}{*}{$\begin{array}{l}\text { Willingness to dispose of sharps } \\
\text { correctly \& learn proper disposal }\end{array}$} & 2 & 3.88 & Positive & \multirow{4}{*}{3.79} & \multirow{4}{*}{ Positive } \\
\hline & 4 & 4.38 & Strongly positive & & \\
\hline & 7 & 3.09 & Neutral & & \\
\hline & 3 & 3.77 & Positive & & \\
\hline \multirow[t]{2}{*}{ Responsibility for needle stick injuries } & 8 & 3.87 & Positive & \multirow[t]{2}{*}{3.84} & \multirow[t]{2}{*}{ Positive } \\
\hline & 9 & 3.90 & Positive & & \\
\hline \multirow{4}{*}{$\begin{array}{l}\text { Desire to prevent needle stick injury } \\
\text { Belief that improper sharps disposal is } \\
\text { a serious problem } \\
\text { Fear or embarrassment in asking } \\
\text { physician about proper disposal }\end{array}$} & 5 & 4.50 & Strongly positive & \multirow{4}{*}{\multicolumn{2}{|c|}{ Same as per item }} \\
\hline & 1 & 4.27 & Strongly positive & & \\
\hline & 6 & 3.40 & Positive & & \\
\hline & MEAN & $3.90 \pm 0.58$ & Positive & & \\
\hline
\end{tabular}




\begin{tabular}{|c|c|c|c|}
\hline FACTOR & $\begin{array}{l}\text { ODDS } \\
\text { RATIO }\end{array}$ & $\begin{array}{c}\text { P } \\
\text { VALUE }\end{array}$ & $95 \% \mathrm{Cl}$ \\
\hline Disposal advice from family/friends & 2.86 & 0.10 & 0.81 to 10.14 \\
\hline Disposal advice from $\mathrm{HCWs}$ & 2.14 & 0.14 & 0.79 to 5.82 \\
\hline College education (at least) & 2.16 & 0.09 & 0.90 to 5.17 \\
\hline Employment & 1.88 & 0.23 & 0.67 to 5.25 \\
\hline Attitude & 1.21 & 0.61 & 0.58 to 2.50 \\
\hline Use of insulin outside the house & 1.17 & 0.73 & 0.48 to 2.83 \\
\hline Male sex & 1.10 & 0.84 & 0.44 to 2.73 \\
\hline Use of insulin syringes & 1.03 & 0.96 & 0.34 to 3.09 \\
\hline Knowledge & 1.02 & 0.19 & 0.99 to 1.05 \\
\hline Age & 1.02 & 0.39 & 0.98 to 1.05 \\
\hline Duration of DM & 0.94 & 0.04 & 0.89 to 1.00 \\
\hline Use of insulin pens & 0.92 & 0.85 & 0.38 to 2.22 \\
\hline Duration of insulin use & 0.90 & 0.03 & 0.83 to 0.99 \\
\hline Presence of children at home & 0.81 & 0.65 & 0.34 to 1.96 \\
\hline Civil status (married) & 0.78 & 0.56 & 0.33 to 1.82 \\
\hline History of needle stick injury to self & 0.65 & 0.47 & 0.20 to 2.10 \\
\hline
\end{tabular}

\begin{tabular}{|c|c|c|c|c|}
\hline FACTOR & COEFFICIENT & $\begin{array}{c}\mathbf{P} \\
\text { VALUE } \\
\end{array}$ & $95 \% \mathrm{Cl}$ & $\mathrm{R}^{2}$ \\
\hline $\begin{array}{l}\text { History of needle } \\
\text { stick injury to self }\end{array}$ & 0.279 & 0.03 & 0.026 to 0.532 & 0.029 \\
\hline $\begin{array}{l}\text { Education (college } \\
\text { level or beyond) }\end{array}$ & 0.277 & 0.01 & 0.066 to 0.487 & 0.044 \\
\hline $\begin{array}{l}\text { Use of insulin outside } \\
\text { the house }\end{array}$ & 0.196 & 0.07 & -0.018 to 0.410 & 0.017 \\
\hline Use of insulin pens & 0.143 & 0.18 & -0.068 to 0.354 & 0.006 \\
\hline $\begin{array}{l}\text { Advice from health } \\
\text { care workers }\end{array}$ & 0.093 & 0.40 & -0.127 to 0.314 & -0.009 \\
\hline Employment & 0.090 & 0.52 & -0.185 to 0.365 & -0.005 \\
\hline Duration of insulin use & 0.011 & 0.18 & -0.005 to 0.279 & 0.007 \\
\hline Knowledge & 0.004 & 0.17 & -0.002 to 0.011 & 0.007 \\
\hline $\begin{array}{l}\text { Duration of diabetes } \\
\text { mellitus }\end{array}$ & 0.003 & 0.61 & -0.009 to 0.015 & -0.006 \\
\hline $\begin{array}{l}\text { Age } \\
\text { Sex (male) }\end{array}$ & $\begin{array}{l}-0.006 \\
-0.017\end{array}$ & $\begin{array}{l}0.01 \\
0.88\end{array}$ & $\begin{array}{l}-0.014 \text { to } 0.001 \\
-0.232 \text { to } 0.197\end{array}$ & $\begin{array}{l}0.014 \\
-0.008\end{array}$ \\
\hline $\begin{array}{l}\text { Presence of children } \\
\text { at home }\end{array}$ & -0.055 & 0.62 & -0.271 to 0.162 & -0.006 \\
\hline Use of insulin syringes & -0.143 & 0.29 & -0.407 to 0.121 & 0.001 \\
\hline $\begin{array}{l}\text { Advice from family } \\
\text { and friends }\end{array}$ & -0.160 & 0.92 & -0.332 to 0.300 & -0.009 \\
\hline Civil status (married) & -0.275 & 0.01 & -0.478 to -0.071 & 0.046 \\
\hline
\end{tabular}

\section{DISCUSSION}

This study shows that the most common method of disposal for used insulin needles and syringes is through the community disposal system (82\%). This finding is similar to that in India and Pakistan where $84.4 \%$ and $86 \%$ of diabetics use the household garbage bin to dispose of their sharps respectively. ${ }^{13,14}$

The most common containers used to hold sharps were plastic bags and plastic bottles, the latter are typically soft drink or "mineral water" bottles. These containers are readily available in most Filipino households and patients use them as improvised sharps containers. This habit was also observed in the United Kingdom, where empty beer cans, glass jam jars, envelopes, soap packets, and milk containers were used to hold sharps. ${ }^{15}$

Nearly one-third of the respondents (32.6\%) injected insulin while outside the home. This is comparable to the data of Bouhanick where $26.6 \%$ injected insulin while at work. ${ }^{16}$ Of these patients from European countries, 63\% brought their sharps home, whereas 30\% threw the sharps in a garbage bin, very near to the corresponding figures of $66.7 \%$ and $30.9 \%$ observed in the study.

More than half of the respondents (59.7\%) reported having received advice regarding sharps disposal, which is slightly lower than the figure of $64.6 \%$ reported in the U.K. ${ }^{15}$ The study noted that $49 \%$ received advice from doctors, comparable to the figure of $50 \%$ reported by Musselman for U.S. patients. ${ }^{17}$

Only $23.4 \%$ of the respondents said they had previously sought disposal advice from their doctor. This is only slightly higher than the number reported in India at $16.8 \%{ }^{13}$ Data from Europe reported that only $18.3 \%$ of patients inquired from physicians regarding proper disposal, although this figure was reported by physicians and not the patients themselves. ${ }^{16}$

The mean knowledge score of the participants was $62.2 \pm$ $15.7 \%$, corresponding to a fair or moderate level of knowledge, while the mean attitude score was $3.90 \pm 0.58$, which represented a positive attitude. Singh and Chapman assessed 303 Indian diabetic patients and classified $65.9 \%$, $23.8 \%$ and $10.3 \%$ of the participants to have a moderate, high, and low knowledge level respectively. The same authors observed that a low attitude level towards proper sharps disposal was seen in $16.3 \%$, moderate for $67.1 \%$ and high for $16.6 \%$ of patients. ${ }^{13}$ Because of the low Cronbach's alpha associated with this section, this datum is not conclusive. Since the low value is likely a result of the limited number of items, additional items to cover the three knowledge domains are suggested. However, since the questionnaire is already fairly long and the respondents often found this section to be the most challenging, an alternative would be to create a questionnaire focused solely on knowledge of sharps use and disposal. This would ameliorate the potential respondent fatigue or loss of interest that occurs when answering long questionnaires.

Majority of the literature reviewed observed that education regarding proper disposal of sharps had a significant and positive impact on patient practices. However, this study noted that the only factors which reached statistical significance were those that exerted a negative influence, particularly a longer duration of diabetes and insulin use.

Several reasons why advice from HCWs did not have a positive impact can be speculated. First, patients might not have followed the advice given. Second, the advice given might not be correct in the first place. Among the 47 patients who reported a physician and/or a nurse to be the source of advice, only 11 were assessed to have a correct disposal method. Third, multiple sources of advice appear to decrease the possibility of correct disposal. Of the 18 patients who reported receiving advice from more than one source aside from a HCW, none were assessed to be consistently practicing a proper disposal method. 
It was observed that three patients were able to dispose of their sharps at health care facilities. It is a reasonable assumption that if more health care facilities were to offer this service, patients might be less inclined to dispose their sharps in local trash bins. In particular, this population of respondents all had regular outpatient follow-up and could bring their sharps for disposal on their scheduled visit. However, this did not seem to be the case. When the respondents were asked if they were willing to bring their sharps to the hospital for disposal, only $44.1 \%$ of the respondents gave a positive response, $15.7 \%$ were uncertain, and $40.2 \%$ were not amenable. If the respondents that were uncertain are considered to have a negative response, this would mean nearly two-thirds of the respondents were actually unwilling to bring their sharps to the hospital for disposal. The questionnaire was not designed to determine the reasons for this outcome, therefore it is suggested that these be evaluated further, especially if a hospital-based collection sharps program is planned.

The study has shown that patients of the UP-PGH Diabetes Clinic have a positive attitude and appear to have moderate knowledge towards the correct disposal of insulin syringes and needles. Despite this, only $23.7 \%$ were assessed to have acceptable disposal techniques. This implies that adequate attitude and knowledge by itself does not necessarily translate to action. As shown in the Health Belief Model, health-related behavior is influenced by "Cues to Action," which can be regarded as strategies to activate "readiness." 18 Therefore, patients might be ready to commit to health-promoting behavior but require an impetus to push them into action, particularly education on proper sharps disposal.

\section{CONCLUSION}

Majority of patients at the UP-PGH DM clinic do not practice acceptable sharps disposal methods. Factors that negatively impact on safe disposal include longer duration of diabetes mellitus and longer duration of insulin use. No factors appeared to influence knowledge significantly. History of previous needle stick injury and college education influenced attitude towards sharps disposal positively, while being married exerted a negative influence.

Patients of the UP-PGH Diabetes Clinic have a positive attitude and apparently moderate knowledge with regard to sharps disposal. Despite this, less than a quarter of patients dispose of their insulin syringes and needles properly. Therefore, it is highly recommended that educational program on sharps disposal in the community setting be initiated.

\section{Acknowledgements}

We would like to thank the following: Merck, Inc., through the Philippine Society of Endocrinology and Metabolism for the research grant awarded to this study, and Mary Ann J. Ladia, Ph.D. of the Department of Clinical Epidemiology, College of Medicine, U.P. Manila for valuable advice in the construction of the questionnaire.

\section{References}

1. Community Options for Safe Needle Disposal. http://www.epa.gov/osw/nonhaz/industrial/medical/med-govt.pdf. Accessed June 30, 2014

2. The Problem. http://www.safeneedledisposal.org/index.cfm?load= page\&page $=42$. Accessed March 14, 2014

3. Quiwa L, Plata-Que T and Jimeno CA (2010). "Sharps Disposal Practices of Patients at the East Avenue Medical Center Diabetes Clinic." Residency research paper, East Avenue Medical Center Department of Internal Medicine, 2010

4. Brewer NT, Rimer BK. Perspectives on health behavior theories that focus on individuals. http://www.unc.edu/ ntbrewer/pubs/ 2008,\%20brewer\%20\&\%20rimer.pdf. Accessed June 25, 2013.

5. Insulin Storage and Syringe Safety. http://www.diabetes.org/ living-withdiabetes/treatment-and-care/medication/insulin/insulin-storage-andsyringe-safety.html. Accessed January 18, 2014.

6. Do's and don'ts: Safe disposal of needles and other sharps used at home, at work, or while traveling. http://www.fda.gov/downloads/ MedicalDevices/ProductsandMedicalProcedures/HomeHealthandConsu mer/ConsumerProducts/Sharps/UCM278775.pdf. Accessed January 18, 2014

7. Handle with care: How to throw out used insulin syringes and lancets at home. http://www.xubex.com/PDF/hancare.pdf. Accessed January 18, 2014.

8. Scorepak: Item analysis. https://www.washington.edu/oea/pdfs/ resources/item_analysis.pdf. Accessed March 17, 2014

9. Office of measurement and evaluation of teaching. http://www.omet.pitt.edu/docs/OMET Test and Item Analysis.pdf. Accessed March 17, 2014

10. Mitra NK, Nagaraja HS, Ponnudurai G, Judson JP. The levels of difficulty and discrimination indices in type A multiple choice questions of preclinical semester 1 multidisciplinary summative Tests. IeJSME. 2009; 3(1):2-7.

11. Varma S. Preliminary item statistics using point-biserial correlation and p-values.http://www.eddata.com/resources/publications/ EDS_Point_Biserial.pdf. Accessed March 17, 2014.

12. Tucker S. Using remark statistics for test reliability and item analysis http://www.umaryland.edu/cits/services/testscoring/umbtestscoring_test anditemanalysis.pdf. Accessed March 17, 2014.

13. Singh AP, Chapman RS. Knowledge, attitude and practices (KAP) on disposal of sharp waste, used for home management of type-2 diabetes mellitus in New Delhi, India. J Health Res. 2011; 25(3):135-139.

14. Ishtiaq O, Qadri AM, Mehar S, et al. Disposal of syringes, needles, and lancets used by diabetic patients in Pakistan. J Infect Public Health. 2012; 5(2):182-188. http://dx.doi.org/10.1016/j.jiph.2012.02.002.

15. Olowokure B, Duggal H, Armitage L. The disposal of used sharps by diabetic patients living at home. Int J Environ Health Res. 2003; 13(2):117-123. http://dx.doi.org/10.1080/0960312031000098044.

16. Bouhanick B, Hadjadj S, Weekers S. What do the needles, syringes, lancets, and reagent strips of diabetic patients become in the absence of a common attitude? Diabetes Metab. 2000; 26(4):288-293.

17. Musselman K, Sicat BL, Thomas MH, Harpe SE. Patients' knowledge of and practices relating to the disposal of used insulin needles. Innov Pharm. 2010; 1(2): Article 20.

18. Health Belief Model. http://www.utwente.nl/cw/theorieenoverzicht/ theoryclusters/healthcommunication/ health_belief_model/. Accessed March 17, 2014.

Articles and any other material published in the JAFES represent the work of the author(s) and should not be construed to reflect the opinions of the Editors or the Publisher. Authors are required to accomplish, sign and submit scanned copies of the JAFES Declaration: that the article represents original material, that is not being considered for publication or has not been published or accepted for publication elsewhere. Consent forms, as appropriate, have been secured for the publication of information about patients; otherwise, authors declared that all means have been exhausted for securing such consent. The authors have signed disclosures that there are no financial or other relationships that might lead to a conflict of interest. All authors are required to submit Authorship Certifications that the manuscript has been read and approved by all authors, and that the requirements for authorship have been met by each author. 
APPENDIX

QUESTIONNAIRE ON SHARPS DISPOSAL of DIABETIC PATIENTS

DATE:

\begin{tabular}{|c|l|}
\hline \multicolumn{2}{|c|}{ Please write some information about yourself. Put a check $(\checkmark)$ in the boxes ( $\square$ ) } \\
\hline NAME & \\
\hline DATE OF BIRTH & DAY $\quad$ MONTH $\quad$ YEAR \\
\hline \multirow{2}{*}{ TELEPHONE / CELLPHONE NUMBER } & \\
\hline SEX & $\square$ Male $\square$ Female \\
\hline \multirow{3}{*}{ CIVIL STATUS } & $\square$ Single \\
& $\square$ Married \\
& $\square$ Separated \\
& $\square$ Widowed \\
& $\square$ Employed \\
& $\square$ Not Employed \\
& $\square$ Self-employed \\
& $\square$ Retired \\
\hline EMPLOYMENT & $\square$ Up to elementary or elementary school graduate \\
& $\square$ Up to high school or high school graduate \\
& $\square$ Up to college or college graduate \\
& $\square$ Vocational \\
& $\square$ Postgraduate (MS, PhD, MBA, MD, etc.) \\
& $\square$ Others \\
\hline ATTAINMENT &
\end{tabular}

\section{Please answer the following questions.}

1. What YEAR were you first diagnosed with diabetes by a doctor? (If you cannot recall you may write the duration of diabetes in years instead)

2. What YEAR did you start using insulin? (If you cannot recall you may write the number of years you have been using insulin instead)

3. If you no longer use insulin what YEAR did you stop using it?

4. What kind of insulin have you used?

$\square$ insulin bottle (vial)

$\square$ insulin pen

$\square$ both insulin bottle and pen

5. Do you have children at home? 


\section{Put a check mark $(\checkmark)$ on the box $(\square)$ of your answer of choice.}

1. Which of the following are the methods you use in disposing your used insulin syringes?

(You can choose more than one answer)

$\square$ Thrown directly into the garbage can mixed with the household trash

$\square$ Thrown into the garbage can but placed in a container like a bag or bottle

$\square$ Placed in a container like a bag or bottle and given to the garbage man

$\square \quad$ Buried in the ground

$\square \quad$ Burned

$\square \quad$ Others (specify)

2. Where do you place your used insulin syringes just before disposing them?

(You can choose more than one answer).

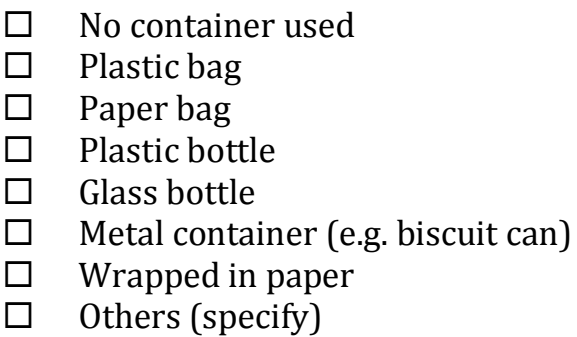

3. Do you inject insulin when you're outside the house?

$\square \quad$ No
$\square \quad$ Yes

If yes, how do you dispose of your used insulin syringes?

$\square \quad$ I bring them home

$\square \quad$ I throw them in any available trash can

$\square$ I throw them anywhere

$\square$ Others (specify)

4. Who of the following have given you advice on how to dispose of your used insulin syringes?

$\begin{array}{ll}\square & \text { Doctor } \\ \square & \text { Nurse } \\ \square & \text { Pharmacist } \\ \square & \text { Friends } \\ \square & \text { Family members } \\ \square & \text { None } \\ \square & \text { Others (specify) }\end{array}$

5. Have you ever accidentally pricked yourself with your insulin syringes?

No

Yes

6. Aside from yourself, has anyone else been accidentally injured by your insulin syringes?

No

$\square \quad$ Yes

If yes, who are these? 


\section{Read the questions carefully. ENCIRCLE the answer that in your opinion is the most appropriate.} Choose only ONE answer per item and please leave no question unanswered.

1. You plan to reuse your insulin syringe. What should you do after using it for the first time?
A. Put the cap back on
B. Clean the needle with alcohol
C. Store the syringe in the freezer
D. Sterilize the needle with a flame

2. While injecting insulin, the insulin syringe slips out of your hand and falls to the ground. What should you do?
A. Use the syringe that fell but clean it with alcohol first
B. Wipe the syringe with a clean cloth then use it
C. Throw away the syringe and use a new one
D. Just use the syringe like nothing happened

3. Which infectious disease can you get after being accidentally pricked by a syringe used by another person?
A. Dengue
B. Tetanus
C. Cancer
D. Hepatitis

4. Who of the following persons in the community is at greatest risk of getting accidentally pricked by used insulin syringes?
A. Garbage scavengers
B. Midwife
C. Teacher
D. Street vendor

5. You have young children in your home and you are concerned that they might play with your used or unused insulin syringes. Where is the best place to store your insulin syringes?
A. In the refrigerator, along with your insulin
B. In a high cabinet that is hard to reach
C. In a hidden place like underneath your clothes
D. In a drawer without a lock

6. If you inject insulin while outside the house, what should you do with the used insulin syringe?
A. Throw them in the nearest garbage can
B. Flush them down a toilet
C. Bring them back home
D. Throw them in the street

7. Used insulin syringes are best
A. Recycled like newspaper and bottles
B. Burned in the backyard
C. Given to other diabetics who use insulin so they can reuse them
D. Given to the garbage man for disposal

8. Which of the following is the best way to dispose of used insulin needles and syringes?
A. Flush them down the toilet
B. Bury them in the ground in your backyard
C. Place them in a puncture-resistant container and dispose with household waste
D. Burn them in your backyard

9. What is the best container for storing used insulin syringes or needles safely?
A. Plastic bottle
B. Glass bottle
C. Plastic bag
D. Metal can with no cover

10. What should you do before throwing away your used insulin syringe?
A. Pull out the needle using pliers
B. Cover the needle with the cap
C. Bend the needle
D. Cut the needle with scissors 
III. ENCIRCLE your answer of choice. Do not leave any question without an answer.

\begin{tabular}{|c|c|c|c|c|c|}
\hline & $\begin{array}{l}\text { STRONGLY } \\
\text { AGREE }\end{array}$ & AGREE & UNCERTAIN & DISAGREE & $\begin{array}{l}\text { STRONGLY } \\
\text { DISAGREE }\end{array}$ \\
\hline $\begin{array}{l}\text { 1. The improper disposal of insulin } \\
\text { syringes is a serious problem. }\end{array}$ & 5 & 4 & 3 & 2 & 1 \\
\hline $\begin{array}{l}\text { 2. I do not want to learn how to dispose of } \\
\text { my used insulin syringes safely. }\end{array}$ & 5 & 4 & 3 & 2 & 1 \\
\hline $\begin{array}{l}\text { 3. It is the fault of garbage men if they get } \\
\text { injured by insulin syringes and needles } \\
\text { thrown in the trash. }\end{array}$ & 5 & 4 & 3 & 2 & 1 \\
\hline & $\begin{array}{l}\text { STRONGLY } \\
\text { AGREE }\end{array}$ & AGREE & UNCERTAIN & DISAGREE & $\begin{array}{l}\text { STRONGLY } \\
\text { DISAGREE }\end{array}$ \\
\hline $\begin{array}{l}\text { 4. I want to improve my present method } \\
\text { of disposing insulin syringes and } \\
\text { needles. }\end{array}$ & 5 & 4 & 3 & 2 & 1 \\
\hline $\begin{array}{l}\text { 5. I do not want other people to get } \\
\text { injured by my insulin syringes and } \\
\text { needles. }\end{array}$ & 5 & 4 & 3 & 2 & 1 \\
\hline $\begin{array}{l}\text { 6. I am afraid or embarrassed to ask my } \\
\text { doctor how insulin syringes and } \\
\text { needles should be disposed of properly. }\end{array}$ & 5 & 4 & 3 & 2 & 1 \\
\hline $\begin{array}{l}\text { 7. I am willing to bring my used insulin } \\
\text { syringes to the hospital if the hospital } \\
\text { will dispose of them. }\end{array}$ & 5 & 4 & 3 & 2 & 1 \\
\hline $\begin{array}{l}\text { 8. It is my fault if my used insulin syringes } \\
\text { and needles injure someone. }\end{array}$ & 5 & 4 & 3 & 2 & 1 \\
\hline $\begin{array}{l}\text { 9. The proper disposal of insulin syringes } \\
\text { is solely the responsibility of the } \\
\text { government. }\end{array}$ & 5 & 4 & 3 & 2 & 1 \\
\hline
\end{tabular}


IV. ENCIRCLE your answer of choice.. Do not leave any question without an answer.

\begin{tabular}{|l|c|c|c|c|c|}
\hline & ALWAYS & OFTEN & SOMETIMES & RARELY & NEVER \\
\hline $\begin{array}{l}\text { 1. I recap my insulin syringes before } \\
\text { disposing them. }\end{array}$ & 5 & 4 & 3 & 2 & 1 \\
\hline $\begin{array}{l}\text { 2. } \begin{array}{l}\text { I use my insulin syringes or needles } \\
\text { more than once. }\end{array} \\
\begin{array}{l}\text { 3. I pull out or cut the needles of my } \\
\text { insulin syringes before throwing them } \\
\text { away. }\end{array}\end{array} \quad 5$ & 4 & 3 & 2 & 1 \\
\hline $\begin{array}{l}\text { I keep my insulin syringes away from } \\
\text { children or other people }\end{array}$ & 5 & 4 & 3 & 2 & 1 \\
\hline
\end{tabular}

\section{Put a check mark $(\checkmark)$ on the box $(\square)$ of your answer of choice.}

Have you asked your doctor how used insulin syringes and needles should be disposed of properly?

$\square$ No

$* * * * *$

Thank you for answering this questionnaire! 